DOI: 10.2478/auseur-2021-0007

\title{
Courage, Success, Faith...? But Now What Is Courage in Politics?
}

\author{
Nóra BARNUCZ \\ University of Public Service, Faculty of Law Enforcement, Department of Foreign \\ Languages for Specific Purposes \\ e-mail: barnucz.nora@uni-nke.hu
}

\section{A Review of the Volume}

Ferenc Bódi, Andrea Ragusa, Ralitsa Savova (eds.): Courage in Politics ${ }^{1}$

The review is written about the volume Courage in Politics. Its editors are Ferenc Bódi, Andrea Ragusa, and Ralitsa Savova. Ferenc Bódi, $P h D$ - senior researcher at the Institute for Political Science at the Centre for Social Sciences - obtained his $\mathrm{PhD}$ degree at Budapest University of Economic Sciences and Public Administration (Corvinus University) in 2013. Andrea Ragusa (1974-2018) was a professor of contemporary history at the Department of International and Political Science at the University of Siena, where he was also the Director of the Interuniversity Center for Social Change and Innovation. He was member of the editorial boards of the scientific journals Ricerche Storiche and Storia e Futuro and member of the Board of Directors of Fondazione di Studi Storici 'Filippo Turati' in Florence. Ralitsa Savova is an External Associate at the Center for Social Sciences of the Hungarian Academy of Sciences. She is also member of the editorial committee of the above mentioned Storia e Futuro, member of the International Scientific Committee of Amelio Tagliaferri, and an official representative for Central and Eastern Europe of the European cultural route Longobard Ways across Europe. She is a lecturer in cultural tourism in Bulgaria and Hungary. Ralitsa Savova is a doctoral candidate in the Social and Economic Contexts of Human Resources Program at István Széchenyi Doctoral School of Management and Organizational Sciences of the University of West Hungary. The reviewer of the volume is Mihály Fónai, PhD, professor of sociology at the Faculty of Law of the University of Debrecen, who has an MA degree in history and cultural studies.

The title of the review is related to the way of thinking that the authors also emphasize on the back of the cover, as they intended the volume to provide a platform for an interdisciplinary approach to courage in politics, discussing it from

1 Published by Pacini Editore Srl., Saggistica, 2020. ISBN 978-88-6995-729-1. 
different points of view. It can be stated that the authors made an excellent use of this opportunity as each study approaches the theme of the book from different aspects, emphasizing the rich and important research areas of the discipline and drawing the reader's attention to this. The discipline is highlighted from the aspects of success, faith, virtue, the excellent metaphor of the top of the mountain, the different personal characteristics or gender differences. Due to this, it is clear that the theme discussed in the book is a sufficiently complex set of factors.

The 200-page book published by Saggistica contains ten studies by nine authors, including the introduction. Ferenc Bódi and Árpád Szécsi are the authors of two independent studies. It includes a three-authored study written by Andrea Toldi, Gergely Fábián, and Thomas R. Lawson. The studies essentially present historical events with the aim of going beyond the scope of the current interpretation, applying new perspectives in order to offer the revealed historical events in a new way of reading. The studies seek to approach the theme of political courage from several aspects while highlighting the bold and remarkable actors of different eras, who, at that time, approached politics recklessly and made their decisions in the enlightenment of the authors.

The book was basically created in the honour and memory of Associate Professor Andrea Ragusa. Although Andrea Ragusa is one of the co-authors of the volume, unfortunately he could not live the publication of the book as he died unexpectedly on 13 October 2018, at the age of 44, due to his illness. For this reason, it begins with a brief presentation of Andrea's life, in which the reader can learn about the main stages of the author's life. Andrea Ragusa was born on 25 May 1974 in Orbetello, Italy. He graduated from the University of Siena with a degree in history. After graduation, he specialized in Germany and France. In 2005, he became an Associate Professor of Contemporary History at the Faculty of Political Science at the University of Siena. Since 2011, he had been the Director of the Inter-University Centre for the History of Social Change and Innovation and Member of the Scientific Committee and of the Board of the Filippo Turati Historical Research Foundation in Florence. Thanks to his talent and hard work, he became a prominent figure in the field of history and cultural heritage, had a successful academic career as a university professor, and his research achievements have been widely recognized both nationally in Italy and internationally in Europe.

Ferenc Bódi's study Courage in Politics focuses on two elements of the Hungarian Revolution of 1956. On the one hand, the author studies the motives for courage as a virtue, which is the supposed moral motivation of freedom fighters; on the other hand, he interprets the elements of injustice, counterfeiting, the phenomenon of the fake revolutionary, and the typical leading characters of crises and crisis solutions. The research focuses on the profile of the Hungarian freedom fighter and on the personality of János Kádár, who, by accepting the power offered by Moscow, became the leading trickster of the restoration without any compromises. 
The author aims to go beyond the scope of the current interpretation, apply new perspectives, and give the already explored historical events a new reading. The aim of the author is to present the reconstruction after the revolution, which is also valid in a more general framework, because it is not only observed in the case of the Hungarian revolution. The events of 1956 outlined that communism is the product of the typical 'trickster' phenomenon, the embodiment of a false development that disguised a terrible tyrannical system since tricksters show up in all political sides, this being a peculiar form of behaviour. The period in question (1963-1978) is also called the Kádár era, or goulash communism. The mentioned time-span is the peak period of the Kádár era since between 1956 and 1962 and between 1978 and 1988 Kádár was also the actual leader of Hungary. New reforms were triggered by the latent effect of the 1956 revolution launched in Hungary, making the country more liveable in the Eastern Bloc.

In his following study, Ferenc Bódi deals with the political and anthropological interpretation of the 1956 Hungarian revolution, in which the author's aim is to arouse the reader's interest in whether participation in the revolution is a sign of courage or recklessness. He seeks to provide an answer to the explanation of the revolution after the Kádár retaliation and during the Kádár restoration by contrasting the opposites of 'Falsehood and Deception'. The author emphasizes that the Hungarian Revolution of 1956 ended without a real compromise, the new system created a false world, raised a false value system over true virtues, and in this new world courage was replaced by compromise and righteousness by falsehood. The greatest lesson of the upheaval of the $20^{\text {th }}$ century is the compliance with the moral criteria, which promotes the possibility of effective negotiations and the chance of lasting agreements on which our culture is built. The good political practice and the fair profit economy can work only within a given and unified moral framework.

Thomas R. Lawson, PhD, is a Professor Director of International Programs at the University of Louisville in the United States and staff member of the University of Applied Sciences in Munich. The President of Hungary awarded him the title of Knight's Cross of the Order of Merit. He was appointed a Distinguished Professor of the International Service by the University of Louisville. He has published more than 50 articles, book chapters, and books in many countries, including Russia, Poland, England, South Africa, Hungary, and Germany. The American professor approaches the subject of political courage from a completely different viewpoint. The paper titled The Promised Land, A Mountaintop and Political Courage: A View from The Ground reveals that the author applies the endowments of nature to examine the subject of political courage. The first question of the paper is rather generic: 'Courage - political courage - what is it, how do we recognize it, how can we do it?'2 (Lawson 2020: 39). After raising the question, the author takes the reader

2 Thomas R. Lawson (2020). The Promised Land, a Mountaintop and Political Courage: A View From The Ground. In: Bódi, Ferenc-Ragusa, Andrea-Savova, Ralitsa (eds.), Courage in Politics. 
closer and closer to the topic and to the answer to the question. To reach this aim, however, he distinguishes between the interpretations of the concepts of courage and political courage. He explains that, in general, in countries and different cultures, people who oppose oppression, lies, and subjugation as well as those who have stifled self-expression and the human spirit have been considered as brave since time immemorial. In contrast, political courage in the specific sense appears when people are helped out to reach the hilltop, the place where they are no longer oppressed, subjugated, that is, where they do not have to follow falsehoods, a place where their spirits can live and express themselves. Climbing the hilltop requires political courage. However, the great virtue and worthy conclusion of the study is the author's idea that political courage can make the hilltop the residence for everyone, not just the powerful or the élite. Regardless of name, political courage is needed to be able to help others get to the top of the hill so that they can live in the glorious city and live in the promised land.

Nuno Morgado, $\mathrm{PhD}$, is an expert in geopolitics and foreign policy. He is an external researcher at the Hungarian Academy of Sciences as well as a postdoctoral researcher at Corvinus University of Budapest and an Assistant Professor of geopolitical studies at Charles University, Prague. The main aim of his research was to test the impact of the geographical setting on foreign policy. The purpose of his study titled Anti-Communism in Salazar's Portugal and the Hungarian Uprising of 1956 is to examine the response of the Portuguese government and society to the Hungarian Uprising of 1956. The main research question of the study is how the Portugal government and society reacted to the Hungarian Uprising of 1956. According to the author, Salazar was characterized by the hallmarks of honesty, rectitude, and decency, and he was a successful academic, a Catholic, patriot, and proponent of the traditional and limited political power.

János Elöd Kávássy, $P h D$, is a research fellow at the Research Institute and Archives for the History of the Hungarian Regime Change, with more than 40 publications. In 2013, he defended his PhD dissertation on the Hungarian-American relations at Pázmány Péter Catholic University. In his study From Sound to Square Silence, he also focuses on the tragedy of the Hungarian Revolution and the War of Independence of 1956. According to the author's basic hypothesis, many efforts were made in the last thirty years in order to make this period a profound part of our national memory, yet there is still a lack of the complete and valid story that can be absorbed into the Hungarian psyche and become part of it. The study seeks to unfold an unusual character, one of the forgotten heroes of 1956. Márton Rajki was a key figure in the local revolution of Újpest, a family-centred man who did his best to reach a reasonable compromise between the parties in dispute for the sake of humanity. Márton Rajki was a man of principles, devoted to Christian ideals; he rejected armed conflicts in order to prevent the Soviet military invasion in Újpest. He sought peace at all costs, which eventually cost his life. If Márton Rajki was 
'guilty' of anything when he died on 30 July 1959, it was his benevolent naivety, as he was always looking for compromises and peaceful solutions, consciously avoiding the possibility of violence. He believed that dialogue and consensus could replace the oppression and terror of the ruling communist regime and self-defence. The protagonist's behaviour reflected the lessons he learned throughout his devoted Christian life about the moral values represented by Christianity, from his deep conviction that the peaceful good always overcomes the aggressive impulses of evil.

Dániel Oross, $\mathrm{PhD}$, is a political scientist. He received his $\mathrm{PhD}$ in political sciences at Corvinus University of Budapest in 2015. He has been a researcher at the Institute of Political Science in the Centre for Social Sciences since 2011 and member of the Management Committee of COST Action (constitution-making and deliberative democracy) since 2018. His research interests include political participation, youth policy, political socialization, and democratic innovations. In his study Youth Policy between 1956 and 2016 in Hungary, he shares the opinion that youth policy is a product of modern societies that have recognized the need for an integrated approach to young people's needs and demands. The spread of this policy has provoked conflicts in several countries, claiming that young people are usually less bound by social responsibilities than other groups of society. Youth played an important role in the revolutionary changes of the Hungarian history, but as this brief overview has shown, beyond the revolutionary changes, their political representation has always been weak. The study presents the role of young people in the Hungarian Revolution of 1956, and the author gives a brief explanation of how Hungarian decision-makers have understood the need for a new approach to young people in order to avoid similar rebellions. The protracted transformation of the Hungarian youth policy (from youth camps to youth festivals) is far from being finished: due to the results of the recent youth studies, new challenges have to be faced as the Hungarian young people became screenagers in the 2010s.

After the historical presentation of the 1956 Hungarian Revolution and the War of Independence, we can read the study Female Courage dealing with gendercentred social policy issues of political courage, written by (1) Andrea Toldi. She is a language teacher, has worked as the network coordinator of the Division for Strategic Educational Planning and CEEPUS of the Faculty of Health Sciences at the University of Debrecen and currently works at the Department of Training Development at the Faculty; (2) Gergely Fábián, PhD, sociologist - is the Head of the Department of Social Sciences at the Faculty of Health, University of Debrecen. He received his $\mathrm{PhD}$ at Eichstätt Catholic University in Germany and became a habilitated doctor at the University of Debrecen in 2010; and (3) American Professor Thomas R. Lawson. The study begins with a quote from Sir Winston Churchill: 'Success is not final; failure is not fatal: it is the courage to continue that counts.' At the beginning of the study, the authors point out that anyone at any time can list great, charismatic politicians or historians, statesmen, generals, kings; however, 
female politicians or women who have been influenced by history, cannot really be named. Apparently, a man can be a great king, a battle leader, a general, or a knight, but for a woman to be a politician, to take the lead, or to raise her voice for something or someone, requires courage. The authors emphasize that today more and more women are taking an active role in political life or are playing the role of a historian, while in the countries of the Middle or Far East it is still surprising if a woman becomes a prime minister or attains a high political position. In Europe or in the United States, it seems more accepted or more natural if a woman is elected to be the president of a country or the president of the European Commission or the Chairman of the European Central Bank.

In their study, the authors conclude that when a woman tries to step out of a traditional family role, she immediately faces obstacles and is considered as being strange, 'different', or rebellious. The authors conclude that women are motivated by different characteristics to perform courageous actions - namely faith, love, passion, compassion, inner conviction, motherhood, or patriotism, but these can also be the results of external forces. Inner beliefs can motivate women to confront injustice in order to stand up for the weak. Faith can make them fight for their own truth and belief, compassion can lead to forgiveness, and patriotism can be the engine of heroic actions for the nation. Of course, these motivational factors cannot be separated; they occur in different combinations, and their strengths can be additive and may lead to courageous actions. Sir Winston Churchill's quotations in this article are universal, inspiring everyone regardless of gender as the character strengths and virtues cannot be understood exclusively by one gender. The connection between the two pillars of the article can be well illustrated through one of Churchill's famous sentences: 'All the great things are simple, and many can be expressed in a single word: freedom, justice, honor, duty, mercy, hope' (Sir Winston Churchill).

The author of the last two studies is Árpád Szécsi, $P h D$, candidate at the Doctoral School of Political Science at the Faculty of Law, Eötvös Loránd University, Budapest. His research topic focuses on the early period of the Hungarian Democratic Forum (HDF), the leading party of the freely elected governing coalition in 1990. In his study Pre-History of the Hungarian Democratic Forum as an Intellectual and Political Movement, the author concentrates on the pre-history of the party winning the first free general elections in 1990, namely the Hungarian Democratic Forum (HDF), provides an overview of the intellectual and political antecedents and of the decisive period of its becoming a latent network, and describes the preparation for the famous Lakitelek Conference in September 1987, where the HDF was founded. In the second study, titled From the Tent to the Parliament. The Early Period of the Hungarian Democratic Forum (1987-1990), the author states that the roots of the HDF go back to the 1956 revolution both in the spiritual and moral dimensions, having been grown into a national organization of more than thirty 
thousand members and become a political party in the summer of 1989. In the spring of 1990, the HDF was elected as the party with the most numerous mandates, continuing its historic journey 'from the Tent to the Parliament'. The number of members of the movement grew intensively, and it became a major political power of the regime change, eventually winning the free 'founding elections' in 1990. To achieve all this, risks had to be taken, either by the organizers/leaders or by those who sometimes had to endure discrimination and punishment. Therefore, it was the way of political courage that led to the restoration of freedom.

In addition to the personal purpose of writing the book, it is useful for any professional who deals with or wishes to deal with political science or historical research. The authors recommend it to all who wish to observe factual historical events from a critical and new perspective. The authors studied 'political courage' from different aspects regarding courage in certain eras and situations. A significant part of the examples deal with the Hungarian history specifically or indirectly. Moreover, they also capture the general human aspects of 'courage'. In the light of the above, the message of the volume evokes mixed emotions in the reader and draws the reader's attention to courage on the one hand, and it highlights the importance of fair, honest norms, which can only more or less prevail in reality on the other hand. 